\title{
Interjú Erdősi Ferenccel
}

\section{Interview with Ferenc Erdősi}

\section{HAJDÚ ZOLTÁN}

Milyen családi, középiskolai, egyetemi hatások befolyásolták az oktatói, majd kutatói pályaválasztásodat?

Pályaválasztásom nem valamiféle a gyermekkoromig visszavezethető következetes törekvés, tudatos életpálya-építés következménye, hanem ellenkező „előjelü" és erősségü hatások eredője. Nyugdíjas apám azt akarta, hogy mielőbb keresőképes legyek, ezért a cisztercitáknál eltöltött (az általános műveltségem szempontjából jótékony hatású) négy év és az egyházi gimnázium államosítása után közgazdasági technikumba íratott. Ez az iskola a Rákosi-korszakban semmiféle elméleti közgazdasági ismeretet nem adott - a szakképzés a számvitelre szorítkozott. Érettségi után nem éltem a jól fizetett főkönyvelő-helyettesi állásajánlattal, helyette elmentem Szegedre, és földrajz-földtan (majd 1955-től történelem) szakos hallgató lettem. E döntésemet az motiválta, hogy a technikumban földrajzból az osztályban csak nekem volt 7-es osztályzatom, de a kémia-technológia tantárgyból is kiemelkedő teljesítményt nyújtottam.

Az egyetemen rengeteg egzakt természettudományi, továbbá erősen ideologikus társadalomtudományi tárgyból vizsgáztunk, azonban tartalmukat az oktatáspolitika olymértékben „egyenirányúsította”, hogy a vonatkozó szakirodalom mellőzése miatt csupán „egykönyvü” tudásra tehettünk szert. A kivételek közé tartozott Prinz Gyula és Korpás Emil, akik dacolva a dogmatikus tematikával, üdítő tudományközi ismeretekkel tágították látókörünket.

A szegedi, majd a budapesti egyetemen appercipiáltak, továbbá a legkülönbözőbb profilú iskolákban (különösen a bányaipari technikumban) tanárként eltöltött nyolc év alatt szerzett szerteágazó ismeretek birtokában (1964-től) élvezettel tanítottam a Pécsi Tanárképző Főiskola Földrajzi Tanszékén több természeti földrajzi tárgyat, és 31 évesen tettem meg az első lépéseket a tudományos kutatásban, 1966ban doktoráltam Jakucs professzornál (summa cum laude eredménnyel).

Hogyan függött össze a témaválasztásaid sorozata Péccsel és a tágabb környezettel?

Kezdetben erősen, azonban később kiléptem a lokális/környéki körből, majd fokozatosan regionális és országos léptékűvé szélesítettem kutatási terü-

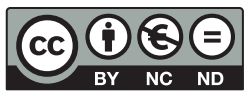


letemet. Az utóbbi évtizedekben pedig európai nagyrégiókról, Európáról és más kontinensekről publikáltam átfogó ágazati munkákat, illetve némely globális problémáról is megfogalmaztam véleményemet.

Első témám a legkülönbözőbb antropogén hatások által valamennyi geoszférában kiváltott folyamatoknak és következményeiknek kutatása volt. Erre föként a pécsi bányavidéki barangolásaim alatt szerzett impressziók sora, a szőlővidéken tapasztalt döbbenetes méretü denudáció és a kétezer éves város archeológiai szintjeinek megismerése inspirált. A technogén változások értelmezéséhez jól tudtam hasznosítani a helyi bányaipari technikumban elsajátított geotechnikai/bányaművelési szakismereteimet. A földtani-geomorfológiai természeti és antropogén jelenségek rendkívüli változatosságát kihasználva jó feltárásoknál tartottam órákat a hallgatóknak a látottak elemzésével és az azokból a lezajlott folyamatokra tehető következtetések megfogalmazásával.

Hogyan szakaszolnád saját pályaivedet a kutatási témák és a meghatározó publikációid alapján?

Kutatói pályám első szakaszát tematikailag sajátos kettősség jellemezte. Az MTA Dunántúli Tudományos Intézetébe kerülve egyéni témaként kiteljesítettem és befejeztem a természeti környezetben tetten érhető különböző antropogén hatások kutatását, de „hivatalosan” a régió gazdaságföldrajzával kellett foglalkoznom. A Mecsek és tágabb környékén antropogén hatásra bekövetkezett változásokról 1977-ben védtem meg kandidátusi értekezésemet (max. pontszámmal), mely az Akadémiai Kiadó gondozásában jelent meg. Intézeti témaként a Dél-Dunántúl épitőanyag-iparának földrajzát választottam olyan megfontolásból, hogy az iparág allokációjának értékeléséhez hasznositthatom földtani ismereteimet. Ezen túlmenően a közlekedési pályák teljesítőképessége és a szállítási költségek alapján meghatároztam a kőbányák, a nagyobb kavicsbányák és a téglagyárak optimális szállitási körzetét az új gazdasági mechanizmus szellemében.

Bármennyire is elégedett lehettem intézeti témám hozadékával (publikálásban, gyakorlati hasznosításban), jó néhány - levéltári kutakodást és terepbejárást igénylő - téma felkeltette érdeklődésemet, amelyeket a saját szakállamra kutattam.

Pályaívem e második (vegyes tematikájú) időszakában főként településtörténeti és -földrajzi, valamint vízi közlekedési témákban szereztem jártasságot a Dél-Dunántúlra szorítkozva. (Az építonanyag-ipar története, a pécsi bányatelepek kialakulása, a természeti tényezők hatása Pécs városfejlődésére, a folyami kikötő hatása Mohács és Barcs településfejlődésére, a vízszabályozások mezőgazdasági hatásai stb.) Az akkori publikációim közül három monográfiát emelnék ki: „Mohács földrajza” (első fejezete Lehmann Antal munkája), „A pécsi városszerkezet fejlődése és a városrészek funkcióinak alakulása a kapitalizmus korában”, valamint „A magyar söripar földrajzi problémái” címüt.

Munkásságom harmadik - máig tartó - időszaka (nem minden előzmény nélkül) az 1980-as években kezdődött, amikor arra az elhatározásra jutottam, hogy olyan jelentős, a reálszféra részéről is élénkebb érdeklődésre számot tartó témára váltok át, amely évtizedekig művelhető, és amelynek eredményei elegendők lehetnek akadémiai doktori értekezésem megírásához. 
Több opció közül a közlekedés és a területi/településfejlődés közötti kölcsönhatások vizsgálatát választottam, amibe beletartozik a közlekedéshálózat és a forgalom tér- és időbeli alakulását befolyásoló müszaki, földrajzi, gazdasági stb. szempontok szerinti elemzése is a belőle levonható következtetésekkel. A korábbiakat meghaladó kutatási eredmények eléréséhez nélkülözhetetlennek tartottam a hálózat kialakulására ható valós tényezők lehető legrészletesebb megismerését eredeti levéltári anyagokból, mert a témával kapcsolatos korábbi állítások több esetben nem látszottak életszerünek. A primer forrásokból sikerül kiderítenem, hogy az osztrák birodalmi, majd 1867-től a magyar országosnak feltüntetett, valójában gazdasági és regionális érdekeknek milyen drasztikus szerepe volt a vasúthálózat (és ezzel a településhálózat) területi szerkezetének kialakításában, nevezetesen a transzverzálisok építésének megakadályozásában, a mesterséges centralizáció elősegítésében. (E problémakört foglalta össze „A közlekedés fejlődésének területpolitikai vonatkozásai és hatása a területekre és településekre Magyarországon 1944-ig c. monográfiám.)

Az 1980-as évek végén az infokommunikációs technológiai forradalom kibontakozása arra a következtetésre késztetett, hogy a közlekedés és a távközlés/infokommunikáció egyre inkább közös, egymással kölcsönhatásban levő integrált rendszert alkot. E felismerés nyomán dolgoztam ki az új tudományág, a kommunikáció-földrajz elméleti (elvi-módszertani) alapjait. E témából védtem meg 1989-ben (max. pontszámmal) „Kommunikáció és térszerkezet” című akadémiai doktori értekezésemet. Megjelent könyv alakban, majd ezt követte 1992ben a „Telematika” és 2000-ben „A kommunikáció (közlekedés-távközlés) szerepe a terület- és településfejlődésben” könyv.

Hogyan értékelnéd eddigi tudományos eredményeid hatásait a szakmán belül, valamint szélesebb, gazdasági-társadalmi tekintetben? (Ment-e a publikációid révén elörébb a világ?)

A földrajzon (a „, szakmán”) belül maradva, az alapkutatás terén a legnagyobb eredménynek több, kifejezetten új, különleges fontosságú jelenségeket firtató részdiszciplína alapjainak kidolgozását és (Pécsett) az egyetemi (graduális, PhD-) képzésbe önálló tantárgyként való bevonását tartom. (Antropogén geomorfológia..., kommunikáció-földrajz, távközlésföldrajz.) A „Mohács földrajza” című könyv mintául szolgált az MTA FKI Alföldi Csoportja által készített városmonográfiákhoz. Végső soron modern szegmensekkel szélesítettem a magyar geográfia tematikai spektrumát. Egyik tanulmányomat megkérdezésem nélkül lefordították oroszra, és kiadták Moszkvában - a honoráriumról sem megfeledkezve.

A „földrajzon túli” világon belül munkám nem csupán az intézetünk által vállalt kmb-munkákban értékesült, hanem több óriásvállalat (MATÁV, MALÉV, MÁV) által kiadott - müszaki, szakpolitikai és szervezeti témákat is tartalmazó - vaskos szakkönyveimben, továbbá a regionális és megyei vállalatok (Dél-Kő, Pannon Volán, Vendéglátóipari V., Közútfenntartó stb.) számára írt tanácsadó tanulmányokban. A hazánk, Kelet-Európa, Európa és Afrika közlekedéséről írt kézikönyveim (és a közlekedési alágazati tematikájú egyetemi tankönyveim) a Széchenyi Egyetemen, a Miskolci Egyetemen és a BME-n szolgálják a közlekedés-földrajzi, illetve közlekedés-gazdaságtani képzést. 
Szakismeretem hasznosítása egyik legközvetlenebb módjának a különféle tanácsadásokon kívül a Közlekedéstudományi Intézettel közösen végzett (az autópályahálózattal kapcsolatos) munkálkodásomat tartom.

Munkásságom elismerését nyugtázhattam a kormánykitüntetésben, továbbá a különféle közlekedési szervezetek (szakminisztérium, KTE, Mérnöki Kamara tagozata) által adományozott féltucatnyi díjban és oklevélben, valamint a miniszteri biztosi kinevezésben.

A világ „természetesen” aligha ment előre éppen az én publikációim révén, de attól tartok, hogy ezt még igen sok kollegám is így érzi. A geográfia nem bővelkedik Einstein-ekben...

Kiket indítottál el egyetemi oktatóként a tudományos pályán, s „mi lett belólük”?

Az e körbe tartozó kollégák két csoportot alkotnak. Van valami paradox abban, hogy az egykori földrajzszakos hallgatóim közül kerültek ki a legfényesebb karriert befutók, a PTE Természettudományi Kar jó néhány (tanszékvezető) egyetemi docense, sőt egyetemi tanára (Trócsányi A., Wilhelm Z., Pap N., Koltai Dénes). Ellenben a „külsős” (levelező) geográfus és közgazdász PhD-hallgatóim, illetve akiknek témavezetőjük voltam, egzisztenciálisan általában jóval kisebb előmenetelt produkáltak. A tudományos fokozattal megszilárdították pozíciójukat, formálisan növelték presztízsüket, jó esetben egy „csillaggal” előreléptek (pl. adjunktusból docenssé, csoportvezetőből osztályvezetővé).

„Bölcs öregként” milyen szakmai tanáccsal indítanád el ma a kezdő kutatókat?

A kortól és környezettől független bölcsesség igazságtartalma rendkívül szük, és nehezen váltható aprópénzre. Ezért csupán az önismeret és annak birtokában az adottságoknak megfelelő célkitüzés fontosságát húznám alá. Fel kell mérni, hogy az egyéni képességek és a külső körülmények (családi helyzet, anyagi háttér, munkavállalási lehetőségek más ágazatokban stb.) alapján mit kezdhetünk önmagunkkal.

A jövőben tovább keményedő versenyhelyzetben saját kútfőből feltehetően csak azok tudnak helytállni, akik követni tudják a területi folyamatokat is befolyásoló gyorsuló müszaki fejlődést, valamint mélyreható társadalmi átalakulást, a globalizáció következményeit még a mikroszférában is, és ezért az alapkutatásokon kívül a gyakorlati eredményeket kínáló „alkalmazott” kutatásokra is képesek. Végzettségüktől függetlenül sajátítsák el más tudományok legfontosabb kapcsolódó ismereteit, mert a felmerülő összetett problémákra a leghatékonyabban úgy adható válasz, ha egy személyben vagyunk interdiszciplinárisok. (A hagyományos team-munka jobbára csupán multidiszciplináris.)

A megszállt munkamániások testi és mentális egészségüket kockáztatják, ha nem szakítanak időt a kikapcsolódásra, az értelmiségi léthez nélkülözhetetlen művelődésre, továbbá a testmozgásra.

Az interjút Hajdú Zoltán készítette 2012. szeptember 25-én. 